\title{
Disaster Planning Tips for Senior Adults ${ }^{1}$
}

\author{
Carolyn S. Wilken ${ }^{2}$
}

\begin{tabular}{|c|c|}
\hline Disaster Planning Topics & Special Tips for Senior Adults \\
\hline $\begin{array}{l}\text { Water - } 1 \text { gallon/person/day. } \\
\text { Store at least } 3 \text { days worth. }\end{array}$ & $\begin{array}{l}\text { - Dehydration is a serious health problem for older adults. Store } \\
\text { more than the recommended amount. } \\
\text { - Gallon jugs of water are heavy. Use containers that are small } \\
\text { enough to easily handle. } \\
\text { - Be certain that the caps are easily removable in spite of } \\
\text { arthritis. } \\
\text { - Store extra water if you have pets. } \\
\text { - Water in swimming pools and spas can be used for sanitation } \\
\text { and person hygiene. }\end{array}$ \\
\hline $\begin{array}{l}\text { Food -store 3-day supply of } \\
\text { non-perishable food. }\end{array}$ & $\begin{array}{l}\text { - } \quad \text { Consider special dietary needs. } \\
\text { - Have a manual can opener that you can use. }\end{array}$ \\
\hline $\begin{array}{l}\text { First Aid Kit -one for home } \\
\text { and one for the car }\end{array}$ & - Add anything different that you might need. \\
\hline $\begin{array}{l}\text { Non-prescription drugs - } \\
\text { include pain relief, stomach } \\
\text { medicine, and poison } \\
\text { response drugs. }\end{array}$ & $\begin{array}{l}\text { Keep several day's worth of all vitamins and supplements that } \\
\text { that you use daily. Withdrawal of some supplements can be a } \\
\text { serious problem. }\end{array}$ \\
\hline $\begin{array}{l}\text { Contacts -to notify in an } \\
\text { emergency }\end{array}$ & $\begin{array}{l}\text { - All doctors names, phone numbers, addresses and what they } \\
\text { treat you for (i.e. cardiologist) } \\
\text { - In-town relatives or close friends (all phone numbers) } \\
\text { - Out-of town relatives or close friends (all phone numbers) }\end{array}$ \\
\hline $\begin{array}{l}\text { Important papers - } \\
\text { insurance, birth/death } \\
\text { certificates, bank account } \\
\text { and credit card information }\end{array}$ & $\begin{array}{l}\text { - And, Medicare and/or Medicaid cards } \\
\text { - Living will and medical power of attorney } \\
\text { - Veteran's papers }\end{array}$ \\
\hline
\end{tabular}

1. This document is FCS9198, one of a series of the Department of Family, Youth and Community Sciences, Florida Cooperative Extension Service, IFAS, University of Florida, Gainesville FL 32611. First published: May 2003. Reviewed by Elizabeth Bolton, Ph.D., Department of Family, Youth and Community Sciences. Please visit the EDIS Web site at http://edis.ifas.ufl.edu

2. Carolyn S. Wilken, Ph.D., associate professor, Department of Family, Youth and Community Sciences, University of Florida, Gainesville FL 32611. 


\begin{tabular}{|c|c|}
\hline Disaster Planning Topics & Special Tips for Senior Adults \\
\hline $\begin{array}{l}\text { Time passers -board games, } \\
\text { puzzles, books, paper and pens } \\
\text { for letters and notes, envelopes } \\
\text { and stamps, playing cards }\end{array}$ & - Paperback books weigh less than hardcover \\
\hline $\begin{array}{l}\text { Medical Needs - first aid kit, } \\
\text { extra glasses, names of doctors, } \\
\text { information about prescription } \\
\text { medications }\end{array}$ & $\begin{array}{l}\text { - Also, extra hearing aid batteries } \\
\text { - Wheel chair batteries } \\
\text { - List of serial numbers and styles of medical devises (i.e. pacemakers). } \\
\text { - Information on all prescription drugs-dosage, directions, interactions, } \\
\text { - } \text { refill dates. } \\
\text { Minimum } 2 \text { week supply of all essential medications }\end{array}$ \\
\hline People with special needs & $\begin{array}{l}\text { - Alzheimer's Victims } \\
\circ \text { Register with local police/fire departments } \\
\circ \text { ID bracelet or necklace } \\
\circ \text { Instructions for reaching family member, friends, physician } \\
\circ \text { Information about special or peculiar behaviors } \\
\text { - Diabetics } \\
\circ \text { Special dietary foods } \\
\circ \text { Testing supplies } \\
\circ \text { Emergency insulin supplies that do not require refrigeration } \\
\text { - Bed-Bound Persons } \\
\circ \text { Emergency transportation plan } \\
\circ \text { Supplies of daily care items - bed pads, adult diapers, linens } \\
\circ \text { Dietary needs } \\
\text { - Oxygen Dependent } \\
\circ \text { Oxygen supplies (including alternate power source - such as } \\
\quad \text { battery). } \\
\circ \text { Extra water for oxygen condensers }\end{array}$ \\
\hline $\begin{array}{l}\text { Emotional Support/ } \\
\text { Stress Reduction- Special } \\
\text { pictures, spiritual support, } \\
\text { comfort food, addresses and } \\
\text { phone numbers of friends }\end{array}$ & $\begin{array}{l}\text { - Keep a journal about your experience. } \\
\text { - Form informal 'support group' to share concerns and information. } \\
\text { - Write letters to your grandchildren or other family and friends. }\end{array}$ \\
\hline Evacuation or move to shelter & $\begin{array}{l}\text { - Consider backpacks to put supplies in if you must evacuate or move to } \\
\text { a shelter } \\
\text { - Prearrange transportation with neighbors }\end{array}$ \\
\hline
\end{tabular}

\section{References:}

Psychosocial Issues for Older Adults in Disasters

DHHS Publication No. ESDRB SMA 99-3323

Substance Abuse and Mental Health Services Administration

Center for Mental Health Services

Disaster Preparedness for Seniors by Seniors

Available from your local chapter of the American Red Cross, or online at http://www.redcross.org/services/disaster/beprepared/seniors.html 